\title{
The Impact of Foreign Aid Conditionality on Poverty Alleviation in Bangladesh: A Recipient's Perspective
}

\author{
Mehadi Mamun \\ Victorian Institute of Technology, Australia \\ E-mail: mehadi.mamun@vit.edu.au
}

Received: August 12, 2021 Accepted: September 18, 2021 Published: September 30, 2021

doi:10.5296/ber.v11i3.18927

URL: https://doi.org/10.5296/ber.v11i3.18927

\begin{abstract}
Donors provide aid to the recipient government with conditions to implement some policies so that the recipient government can use aid effectively and able to improve its economic, social, and political situation as well as reduce its poverty. However, concerns have been raised that aid conditionality has promoted reforms that could not reduce the poverty situation in some countries such as sub-Saharan Africa, while some countries in East Asia were able to break out of poverty and find themselves better off than before the conditional aid was accepted. Hence, the purpose of this study is to examine the impact of foreign aid conditionality on poverty alleviation in Bangladesh. The paper is qualitative in nature and a case study on Bangladesh. The study has been conducted by using secondary data, like journal articles, research papers, and Bangladesh government and aid donors' reports. The study finds that Bangladesh has started to show considerable improvement in reducing poverty, though it is still ranking low on the Human Development Index. The findings have important implications for policymakers and captured insights about the foreign aid conditionality in Bangladesh.
\end{abstract}

Keywords: Foreign aid, Conditionality, Poverty, Bangladesh

\section{Introduction}

The deliberate use of foreign aid as a tool to promote the development of recipient countries dates back to the post-World War II era when the majority of the European countries found themselves economically, morally, and physically devastated. Then the United States government, under the so-called Marshall Plan, invested over US \$13 billion to support Europe's reconstruction (Banerjee, 2006). Since then, many forms of foreign aid multilateral, bilateral, private-investment, emergency-aid, for example - have been given to foster reconstruction across the world. However, after the European nations began to recover in the 1950s, foreign aid provision shifted to explicitly support economic development more 
generally (Petroia \& Pacicovschi, 2017; Hattori, 2001). The struggle between communism and capitalism fuelled this re-focus on economic growth. It also encouraged major donors, such as the United States and Soviet Union, to see foreign aid as an extension of foreign policy (Boyce, 2002). During this time, the World Bank and International Monetary Fund were established to promote international monetary stability and to facilitate the expansion and balanced growth of world trade (Stern et al., 2005).

Much foreign aid is what is commonly referred to as 'conditional'. Conditional aid is aid provided by international institutional donors to the governments of developing countries with the requirement that they implement certain proscribed policies. These institutions, such as the IMF and the World Bank, require this in the belief that the adoption of these policies will help to ensure that the aid is used in ways that are more likely to reduce poverty and more broadly improve the economic, social and political situation in the area the aid is targeted (Arndt et al., 2015; Stern et al., 2005; Lastra, 2002). In general, these policies tend to be inspired by neo-classical interpretations of economic development and focus on profit maximization and address some of the more tangible structural impediments to healthy economic growth in recipient countries (Ensign, 2003). It has been argued that in some cases, notably in East Asia, conditional foreign aid has helped to break the cycle of poverty (Guillaumont \& Wagner, 2014; Lowenfeld, 2003; Hockett, 2002). However, much of the literature highlight how other countries have found themselves worse off than before the aid was accepted, in particular those studies on sub-Saharan Africa (Moyo, 2009; ActionAid, 2004; Ovaska, 2003). Therefore, the purpose of this present study will be narrowed to aid conditionality effectiveness for the alleviation of poverty within the context of Bangladeshi society, which is sited in South Asia and trying to come out of poverty for a long time.

\section{The Notion of Foreign Aid and Conditionality}

Foreign aid has in different periods of history played an important role in the development of many countries. Some of the countries which are now industrially advanced and prosperous are included among them. For instance, the United Kingdom received aid from the Netherlands in the $18^{\text {th }}$ century and from the USA in the 1940s during European reconstruction after the Second World War (Rist, 2002). Foreign aid is viewed by Fayissa and El-kaissy (2002) as an important component of the growth paradigm, which influenced development concepts and poverty reduction.

Nevertheless, foreign aid is not given unconditionally. It is generally conditional on the adoption of policies that are often imposed by the donor country. The basic idea underlying conditionality is that bilateral as well as multilateral donors provide aid with conditions to implement some policies so that the recipient government can use aid effectively and able to improve the country's economic situation as well as poverty reduction (Arndt et al., 2015; Stern et al., 2005). Three main rationales behind aid conditionality are identified in the literature. First, conditionality is imposed because the recipient government and the donor have different beliefs on the appropriateness of the policy (Bird \& Willett, 2004). Second, conditionality is needed because even if the recipient government has full ownership of the policy, its implementation may face resistance from domestic interest groups (Lastra, 2002). 
Third, conditionality which is imposed by donors can be a signalling device to the recipient government, which sends a message on its commitment to implement the required policies and maintain a sound economic environment (Arndt et al., 2015; Branson \& Hanna, 2002).

The IMF and the World Bank, which are the key providers of multilateral aid, have used conditionality since their inception in 1944 and 1945 respectively (Malmqvist, 2003). According to Lastra (2002), conditionality has been involved significantly in foreign aid since the 1950s (after the Second World War) for fostering economic development and eliminating poverty quickly. Up to the early 1980s, conditionality largely focused on macroeconomic policies (Morrissey, 2004). Subsequently, however, the complexity and scope of the conditions attached to aid increased significantly as a result of globalization (Stern et al., 2005).

In the 1980s, Structural Adjustment Programs (SAPs) were introduced through conditionality in low-income and transition countries where structural problems were hampering broader economic stability. Structural Adjustment Programs (SAPs) included internal changes (notably privatisation and deregulation) as well as external ones, especially the reduction of trade barriers (Ensign, 2003). Nevertheless, SAPs have been the object of much criticism in the foreign aid debate. For example, Structural Adjustment Programs (SAPs) were criticised by Eldar (2005), Leandro and Schafer (2003), and Dijkstra (2002) for implementing generic free-market policy as well as the lack of involvement from the country.

To increase the recipient country's involvement, developing countries are now (since the late 1990s) encouraged by donors to draw up poverty reduction strategies through a participatory process involving domestic stakeholders as well as external development partners, including the IMF and the World Bank (World Bank, 2004). These poverty reduction strategies essentially take the place of the SAPs. Bird (2004), believes that the increase of the local government's participation in creating the policy will lead to greater ownership, thus better fiscal policy. However, Eldar (2005), argues that the international financial institutions (IFIs), and the countries that fund them, are still overly involved in the policy-making process. Therefore, the development community continues to face questions regarding the appropriate type and nature of the conditions to attach to their aid for development in developing countries.

\section{Overview of the Literature on Foreign Aid's Conditionality}

Conditionality, that is the policies and procedures imposed by the donors to govern the access to and the continuing use of their resources by recipient countries, has always been a very controversial subject. The broadest consensus in the literature about the conditionality is that it is overly and increasingly intrusive (e.g., Koeberle, 2003), infringing national sovereignty (e.g., Drazen, 2002), undermining domestic democratic processes and institutions (e.g., Stiglitz, 2002), and ineffective in bringing about the desired outcomes in terms of growth or reduction in poverty (e.g., Easterly, 2005). This section summarizes some of the arguments made in the literature on the effectiveness of conditionality from different perspectives.

Foreign aid is considered by Arndt et al. (2015) and Bird (2004) as an important component 
for developing country's economic and social development. Foreign aid that is generally conditional on the adoption of some policies and these policies are viewed by Lastra (2002) as a way of helping and thereby making financial support more effective in recipient countries. However, according to Moyo (2009) and ActionAid (2004), many of the poorest countries depend on foreign aid for over half of their national budgets, which give donors strong leverage over policy choices. Threatening to withhold essential loans and grants unless the recipient country agrees to conditionality such as the privatisation of public utilities is an unfair abuse of the power. Moreover, Koeberle (2003) expresses the view that many of the benefits of such privatisations often accrue to private sector companies from the donor countries themselves, which raise concerns about the intentions behind the conditionality of donors.

Authors such as Arndt et al. (2015), Stern et al. (2005), and Feldstein (2004) argue that conditionality is not only legitimate but is affirmatively required because donors provide their taxpayer's money to the problematic country where reforms are needed, and donors impose conditionality with the hope that the recipient government can use aid effectively and able to improve the country's economic, social and political situation. Some authors have tried to defend a broader interpretation of the donor's jurisdiction. For example, Hockett (2002) seems to argue that the words of the 'Articles of the Agreement' give the donor the scope to impose any conditions it considers appropriate, and that recipient countries can simply refrain from accepting if they disagree with these conditions.

However, conditionality imposed by donors is seen by Eldar (2005) and Drazen (2002) as infringing on the sovereignty of recipient countries. These authors argue that every country has the sovereign and inalienable right to choose its economic system as well as its political, social and cultural systems in accordance with the will of its people, without outside interference. Eldar (2005) and Koeberle (2003) raise questions about the legitimacy of the World Bank and the IMF, describing them as unelected and unrepresentative bodies that force developing countries to adopt policies that are not in their own best interests. Drazen (2002) has expressed his concerns about the agreements on conditionality which is reached in non-transparent discussion between small groups of government officials and World Bank (and IMF) representatives without due consideration and participation by stakeholders, including civil society.

Authors such as Arndt et al. (2015) and Hockett (2002) argue that donor's prescriptions are very effective because the donors are better placed than domestic governments to pinpoint inefficiencies in the domestic economy, partly because of its professionalism and expertise, and partly because in many cases a third-party observer can be a better judge and critic of a stagnant and inefficient system. Similarly, in a study, Lowenfeld (2003) shows that some of the donor's prescriptions have been very successful and brought desirable results when it was followed properly by recipient countries. For example, the author has mentioned the austerity package which Mexico committed to implement in 1995 has proved extremely successful, and Mexico was able to pay its debt to the IMF even before it became due.

In contrast, according to IEO (2002), the donor's prescriptions have been ineffective in 
restoring confidence and financial stability. For example, the IEO (2002) report shows several IMF prescription's failures, including: failure to address vulnerabilities in countries' economies; failure to take into account the political feasibility of reform programs and implementation capacity constraints; over-optimistic assessments of the effects of conditionality; inadequate prioritization; insufficient focus on key structural issues; and insufficient attention to social concerns and the need for adequate safety nets. Similarly, Stiglitz (2002) and Tsai (2000) argue that donor's prescriptions actually aggravate the financial situation in recipient countries. For example, the authors mention, donor's prescriptions requiring recipient countries to privatise state-owned enterprises, trade liberalization and foreign direct investment, which may cause severe unemployment when prematurely imposed on developing countries. Moreover, according to Goldstein (2002), in some societies the lack of safety nets to assist domestic workers who might lose their jobs following privatisation or policies of cutting-off food subsidies were a source of acute social and political unrest.

In a study, World Bank (2002) shows that conditional foreign aids are very effective to reduce the poverty level and 60 per cent of conditions which includes several adjustment programs are fulfilled by recipient countries and are able to achieve their socio-economic objectives. However, other studies show that compliance is much more limited. For example, Mosley et al. (2004) examined fourteen countries with World Bank adjustment programs and found that only three have been successful. Similarly, in a study Killick (2004) shows that in 100 World Bank adjustment programs, only 25 percent were successful, most were delayed, and 8 percent were cancelled.

The effectiveness of conditionality for improving the political situation in recipient country is also said to be much more limited. For example, Robinson (2000) states that the influence of aid and conditionality on the democratization processes in Africa in the early 1990s were unsuccessful. Likewise, Crawford (2002) shows that conditions improved in only thirteen out of twenty-nine countries where aid sanctions were applied for political reasons. In only nine of the thirteen could this improvement be partially attributed to donor pressure, and in only two cases was donor pressure significant in bringing about political change. Therefore, the conclusion to be reached from the literature review on aid effectiveness is that there are mixed perspectives about the effectiveness of conditionality on foreign aid.

\section{Aid Conditionality and Poverty Alleviation in Bangladesh}

The concept of poverty is divergent in terms of its dynamics, intricacies, and definitions. According to Deaton (2013) and Hye (2001) poverty, the inability to attain a minimal standard of living, refers to forms of economic, social and psychological deprivation occurring among people lacking sufficient ownership, control over or access to resources to maintain or provide individual or collective minimum levels of living.

In Bangladesh, according to figures provided by the World Bank (2021a, 2021b), poverty declined from 44 percent in 1991 to 15 percent in 2016 (based on the international poverty line of $\$ 1.90$ per person per day) and it is one of the key recipients of aid in the world. According to the World Bank (2021c) and Mamun (2021), Bangladesh received over $\$ 4.4$ 


\section{NI Macrothink}

Business and Economic Research

ISSN 2162-4860

2021, Vol. 11, No. 3

billion in a single 2019 year and Bangladesh's external aid has exceeded $\$ 70$ billion since its independence in 1971. Khatun (2018) and Sen (2004) show that in gross terms the flows of aid from all sources to Bangladesh increased steadily till the late 1980s and, although it has declined somewhat since then, it remains very substantial and contributing the largest part of the Annual Development Programme (ADP) (e.g., the share of foreign aid in financing ADP remained around 30\% in 2016). The following graph presents the percentage of the population living below the international poverty line from 1991 to 2016.

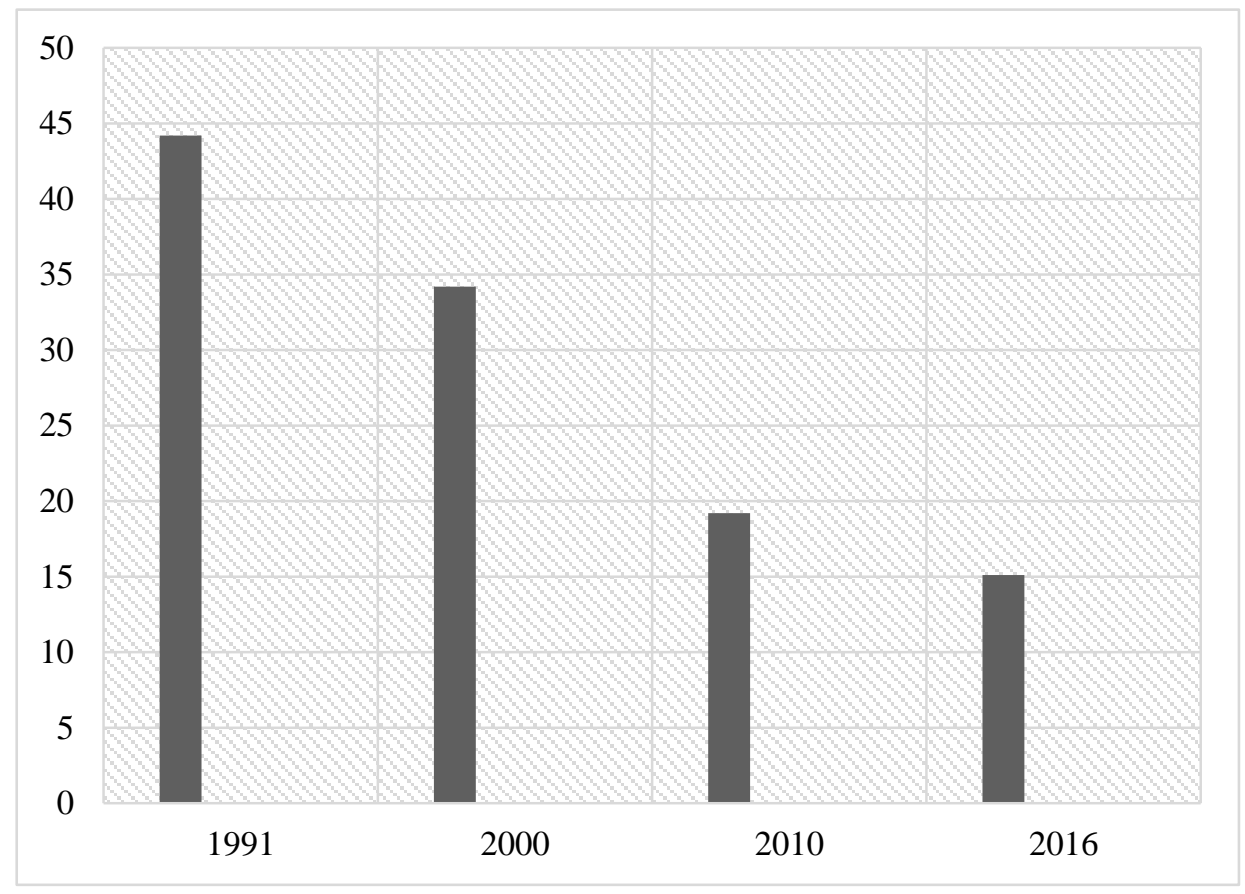

Figure 1. Poverty headcount ratio at international poverty line (\% of Bangladesh's population)

Source: World Bank (2021a, 2021b)

In a study provided by World Bank (2001), a 7 to 8 percent growth rate in GDP would be able to reduce the incidence of poverty in Bangladesh substantially. The World Bank (2021b) and Hossain and Cheng (2003) express that after many years of economic problems, Bangladesh has started to show considerable improvement in economic growth by using conditional aid. They note that the GDP growth rate, which was average at $4.5 \%$ in the $1980 \mathrm{~s}$, has increased to an average of $5.6 \%$ in 2010 and $7.1 \%$ in 2016. In the same vein, The World Bank (2021b) points out that the GNI per capita has increased from $\$ 1,370$ in 2000 to $\$ 5,310$ in 2020 , and the social indicators show a declining birth rate, decreasing morbidity and mortality, rising life expectancy (from average 56 years in 1990 to 73 years in 2020), and an increasing level of secondary school enrolment (from 50\% in 2000 to $73 \%$ in 2020). Hence, the World Bank sees its poverty reduction strategies act as a means of ensuring that aid commitments are focused on the strategies agreed by all parties where donor-government dialogue and the process of setting plans have improved (World Bank, 2021a, 2004). 
However, according to UNDP (2020), all from a low start and the country still remains one of the under-developed countries in the world, ranking $133^{\text {rd }}$ out of 189 countries and territories on the Human Development Index. Inappropriate conditions in foreign aid are perceived by Mamun (2021) and Dijkstra (2002) to be a major obstacle to bring the desired outcomes of aid in Bangladesh. For example, Mamun (2021) finds that international institutional donors' directed privatisation programme has not brought desired outcomes as most of the privatised state-owned organisations were closed down after privatisation. Authors such as Mamun (2021), Curtis (2004), and Khan (2003) also argue that donors do not have a clear perception of Bangladesh's problem and try to apply the same solution to the same problem - even when circumstances are very different. Taking the example of inefficient state-owned enterprises, many donors advise that these should be closed or restructured. Khan (2003) points out that this solution might be suitable in a country where available unemployment benefits helped workers until they found new positions, but Bangladesh has no social security system. Thus, Mamun (2021), Khan (2003), and Santiso (2001) argue that imposed conditions are relatively ineffective in bringing change unless supported by domestic ownership and commitment by the recipient government.

\section{Conclusion}

The purpose of this study is to find out the impact of foreign aid conditionality on poverty alleviation in Bangladesh. The study has attempted to provide a balanced assessment of aid effectiveness research findings, in works that support conditional aid, and others that are critical of it. In some cases, policymakers have found that conditionality is useful and plays a central role to fulfill the objectives of foreign aid. In other cases, conditionality has been criticized as overly intrusive.

The world Bank shows that Bangladesh has started to show considerable improvement in economic growth by using conditional aid and reduced its poverty level from 44 percent in 1991 to 15 percent in 2016. However, this country is still one of the under-developed countries in the world, ranking $133^{\text {rd }}$ out of 189 countries and territories on the Human Development Index. Critics argue that factors such as inappropriate conditions; unclear perception of the country's economic vulnerabilities; failure to take into account the political feasibility of reform programs and implementation capacity constraints; and insufficient attention to social concerns - are the major pitfalls of conditionalities as well as development in Bangladesh. Therefore, as a concluding remark, it can be said that aid conditionality can be effective in helping identify and implement necessary reforms for growth and alleviating poverty but that it is only when there is participation, empowerment, and ownership of the policy by the recipient country. This study, as with most research, cannot stand alone and has limitations. For example, this study is based on secondary information, hence employing different methods with inclusions of stakeholders' thoughts would be worthwhile to consider in future research.

\section{References}

Action Aid. (2004). Money Talks: How Aid Conditions Continues to Drive Utility Privatization in Poor Countries. UK: Action Aid International. 
Arndt, C., Jones, S., \& Tarp, F. (2015). Assessing foreign aid's long-run contribution to growth and development. World Development, 69, 6-18.

https://doi.org/10.1016/j.worlddev.2013.12.016

Banerjee, A. V. (2006). Making Aid Work. USA: The MIT Press.

Bird, G. (2004). Growth, poverty and the IMF. Journal of International Development, 16(4), 621-637. https://doi.org/10.1002/jid.1111

Bird, G., \& Willett, T. D. (2004). IMF Conditionality, Implementation and the New Political Economy of Ownership. Comparative Economic Studies, 46(3), 423-450.

https://doi.org/10.1057/palgrave.ces.8100060

Boyce, J. K. (2002). Unpacking Aid. Development and Change, 33(2), 239-246.

https://doi.org/10.1111/1467-7660.00250

Branson, W., \& Hanna, N. (2002). Conditionality and Policy Learning. Making Development Work Development Learning in a World of Poverty \& Wealth - World Bank on Evaluation \& Development. pp. 43-59.

Crawford, G. (2002). Foreign Aid and Political Conditionality: Issues of Effectiveness and Consistency. Democratization, 7(3), 69-108. https://doi.org/10.1080/13510349708403526

Curtis, D. (2004). How we think they think: thought styles in the management of international aid. Public Administration and Development, 24, 415-423.

https://doi.org/10.1002/pad.328

Deaton, A. (2013). The great escape: Health, wealth, and the origins of inequality. New Jersey: Princeton University Press. https://doi.org/10.1515/9781400847969

Dijkstra, A. G. (2002). The Effectiveness of Policy Conditionality: Eight Country Experiences. Development and Change, 33(2), 307-335.

https://doi.org/10.1111/1467-7660.00256

Drazen, A. (2002). Conditionality and ownership in IMF lending: a political economy approach. Mimeo.

Easterly, W. (2005). What did structural adjustment adjust? The association of policies and growth with repeated IMF and World Bank adjustment loans. Journal of Development Economics, 76(1), 1-22. https://doi.org/10.1016/S0304-3878(04)00087-2

Eldar, O. (2005). Reform of IMF Conditionality: A Proposal for Self-Imposed Conditionality. Journal of International Economic Law, 8(2), 509-549. https://doi.org/10.1093/jielaw/jgi031

Ensign, M. M. (2003). Conditionality and Foreign Assistance. Journal of International Affairs, 42(1), 147-163.

Fayissa, B., \& El-Kaissy, M. I. (2002). Foreign aid and the economic growth of developing countries: further evidence. Studies in Comparative International Development, 34(3), 37-50. https://doi.org/10.1007/BF02687626 
Feldstein, M. (2004). Refocusing the IMF. Finance and Development, 49(3), 40-44.

Goldstein, M. (2002). IMF Structural Conditionality: How Much Is Too Much? Institute for International Economics, Working Paper No. 01-04. https://doi.org/10.2139/ssrn.300885

Guillaumont, P., \& Wagner, L. (2014). Aid effectiveness for poverty reduction: Lessons from cross-country analyses, with a special focus on vulnerable countries. Revue d'économie du développement, 22(HS01), 217. https://doi.org/10.3917/edd.hs01.0217

Hattori, T. (2001). Reconceptualizing Foreign Aid. Review of International Political Economy, 8(4), 633-660. https://doi.org/10.1080/09692290110077610

Hockett, R. (2002). From Macro to Micro to 'Mission-Creep': Defending the IMF's Emerging Concern with the Infrastructural Prerequisites to Global Financial Stability. Asian Business Review, April, 184-189.

Hossain, S., \& Cheng, M. Y. (2003). Bangladesh: building for a better future? International Journal of Social Economics, 29(10), 813-821. https://doi.org/10.1108/03068290210444449

Hye, H. A. (2001). Below the Line: Rural Poverty in Bangladesh. Dhaka: University Press Limited.

IEO. (2002). Evaluation of Prolonged Use of IMF Resources. IMF: Independent Evaluation Office.

Khatun, F. (2018). Can Bangladesh do without Foreign Aid? Bangladesh: Centre for Policy Dialogue.

Khan, A. (2003). Economic development: from independence to the end of the millennium. In R. Jahan (Ed.), Bangladesh: Promise and Performance. New York: Zed Books.

Killick, T. (2004). Politics, Evidence and the new aid agenda. Development Policy Review, 22(1), 5-29. https://doi.org/10.1111/j.1467-8659.2004.00235.x

Koeberle, S. G. (2003). Should policy-based lending still involve conditionality? World Bank Research Observer, 18(2), 249-273. https://doi.org/10.1093/wbro/lkg009

Lastra, R. M. (2002). IMF conditionality. Journal of International Banking Regulation, 4(2), 167-182. https://doi.org/10.1057/palgrave.jbr.2340138

Leandro, J. E., \& Schafer, H. (2003). Towards A More Effective Conditionality: An Operational Framework. World Development, 27(2), 285-300.

https://doi.org/10.1016/S0305-750X(98)00127-2

Lowenfeld, A. (2003). International Economic Law. New York: Oxford University Press.

Malmqvist, H. (2003). Development Aid, Humanitarian Assistance and Emergency Relief. Sweden: Ministry of Foreign Affairs.

Mamun, M. (2021). Privatisation and Employees' Job Security: Lessons from Bangladesh. International Journal of Human Resource Studies, 11(2), 201-215. 
https://doi.org/10.5296/ijhrs.v11i2.18533

Morrissey, O. (2004). Conditionality and Aid Effectiveness Re-evaluated. The World Economy, 27(2), 153-171. https://doi.org/10.1111/j.1467-9701.2004.00594.x

Mosley, P., Hudson, J., \& Verschoor, A. (2004). Aid, poverty reduction and the 'new conditionality'. Economic Journal, 114(496), 217-243.

https://doi.org/10.1111/j.1468-0297.2004.00220.x

Moyo, D. (2009). Dead aid: Why aid is not working and how there is a better way for Africa. New York: Farrar, Straus and Giroux.

Ovaska, T. (2003). The Failure of Development Aid. CATO Journal, 23(2), 175-188.

Petroia, A., \& Pacicovschi, V. (2017). Conditionality of foreign aid and its consequences. Moldova: Academy of Economic Studies of Moldova. https://doi.org/10.2139/ssrn.2977946

Rist, G. (2002). The History of Development: From Western Origins to Global Faith. USA: Zed Books.

Robinson, M. (2000). Aid, Democracy and Political Conditionality in Sub-Saharan Africa. In G. Sorensen (Ed.), Political Conditionality (pp. 85-99). London: Frank Cass/EADI. https://doi.org/10.1080/09578819308426580

Santiso, C. (2001). Good governance and aid effectiveness: The World Bank and conditionality. The Georgetown Public Policy Review, 7(1), 1-22.

Sen, B. (2004). Growth, poverty and human development. In R. Jahan (Ed.), Bangladesh: Promise and Performance. New York: Zed Books.

Stern, N., Dethier, J. J. \& Rogers, H. (2005). Growth and Empowerment: Making Development Happen. Cambridge: The MIT Press.

https://doi.org/10.7551/mitpress/3377.001.0001

Stiglitz, J. (2002). Globalization and its Discontents. London: Penguin.

Tsai, M. C. (2000). Globalization and Conditionality: Two Sides of the Sovereignty Coin. Law \& Policy in International Business, 31(4), 1317-1330.

UNDP. (2020). Human Development Report 2020. New York: UNDP.

World Bank. (2001). Bangladesh, From Counting the Poor to Making the Poor Count. Washington DC: World Bank.

World Bank. (2002). Adjustment Lending: Ten Years of Experience. Washington DC: World Bank.

World Bank. (2004). From Adjustment Lending to Development Policy Lending. Washington DC: World Bank.

World Bank. (2021a). The World Bank in Bangladesh - Overview. Washington DC: World Bank. 


\section{Macrothink}

Business and Economic Research ISSN 2162-4860 2021, Vol. 11, No. 3

World Bank. (2021b). World Development Indicators database. Washington DC: World Bank.

World Bank. (2021c). Net official development assistance and official aid received Bangladesh. Washington DC: World Bank.

\section{Copyright Disclaimer}

Copyright for this article is retained by the author(s), with first publication rights granted to the journal.

This is an open-access article distributed under the terms and conditions of the Creative Commons Attribution license (http://creativecommons.org/licenses/by/4.0/). 